\title{
Retraction Note: New applications of Schrödinger type inequalities to the existence and uniqueness of Schrödingerean equilibrium
}

Jianjie Wang ${ }^{1}$ and Hugo Roncalver ${ }^{2 *}$

The original article can be found online at https://doi.org/10.1186/ s13660-017-1332-0

*Correspondence: hugo.goncalver@gmail.com ${ }^{2}$ Institute of Mathematical Physics, Technische Universität Berlin, Berlin, D-10587, Germany Full list of author information is available at the end of the article

\section{Retraction Note}

The Editors-in-Chief have retracted this article because it shows significant overlap with articles by different authors that were simultaneously under consideration at different journals $[1,2]$. The article also shows evidence of authorship manipulation and peer review manipulation. Additionally, the identity of the corresponding author could not be verified. The Technische Universität Berlin have confirmed that Hugo Roncalver has not been affiliated with their institution. The authors have not responded to correspondence regarding this retraction.

\section{Author details}

${ }^{1}$ College of Applied Mathematics, Shanxi University of Finance and Economics, Taiyuan, 030006, China. ${ }^{2}$ Institute of Mathematical Physics, Technische Universität Berlin, Berlin, D-10587, Germany.

\section{Publisher's Note}

Springer Nature remains neutral with regard to jurisdictional claims in published maps and institutional affiliations.

Published online: 24 November 2021

\section{References}

1. Zhang, J., Lu, J., Du, W., Chu, Y., Luo, H.: Hopf bifurcation analysis and its preliminary control in a Hasting-Powell food chain model with two different delays. J. Nonlinear Sci. Appl. 10(8), 4181-4196 (2017)

2. Lai, M., Sun, J., Li, W.: RETRACTED ARTICLE: Stability and direction for a class of Schrödingerean difference equations with delay. Adv. Differ. Equ. 2017, 87 (2017). https://doi.org/10.1186/s13662-017-1132-3

\section{Springer}

(c) The Author(s) 2021. This article is licensed under a Creative Commons Attribution 4.0 International License, which permits use, sharing, adaptation, distribution and reproduction in any medium or format, as long as you give appropriate credit to the original author(s) and the source, provide a link to the Creative Commons licence, and indicate if changes were made. The images or other third party material in this article are included in the article's Creative Commons licence, unless indicated otherwise in a credit line to the material. If material is not included in the article's Creative Commons licence and your intended use is not permitted by statutory regulation or exceeds the permitted use, you will need to obtain permission directly from the copyright holder. To view a copy of this licence, visit http://creativecommons.org/licenses/by/4.0/. 